\title{
PAST THE GLORIOUS AGE: OLD TESTAMENT SCHOLARSHIP IN SOUTH AFRICA-ARE WE MOVING ANYWHERE CLOSE TO BLACKENING OLD TESTAMENT SCHOLARSHIP?
}

\author{
Hulisani Ramantswana \\ Department of Biblical and Ancient Studies \\ UNISA
}

\begin{abstract}
Old Testament scholarship in South Africa has deepened, broadened, and evolved over the years; and various trails can be traced within it. The article interrogates whether Old Testament scholarship has passed the glorious age. The following issues are explored: First, the retirement of scholars in recent years as a signal of the coming to an end of the second-generation of Old Testament scholars in South Africa; second, the developments in black Old Testament scholarship as a trail which developed alongside white Old Testament scholarship; and third, the prospects of Old Testament scholarship from a decolonial perspective. This article argues that the future of Old Testament Scholarship in (South) Africa is in a blackening, that is, a redress process through broadening of the scholarship to reflect the continent in which it has to thrive.
\end{abstract}

Keywords: Old Testament Scholarship; South Africa; Africa; White; Margins; Blackening

\section{Introduction}

At the 2019 meeting of the Old Testament Society of South Africa (OTSSA), I was invited to participate in a panel which focused on "Reading Old Testament texts in contemporary contexts/Reading the Old Testament in contemporary contexts". The panel included Prof Madipoane Masenya, Prof Gerald O. West and retired Prof Eben Scheffler and me. We were required to focus our discussion on our scholarship and the prospects of Old Testament scholarship in South Africa. As a young scholar in the company of scholars who were at the tail end of their scholarship, I also had to start envisioning the future of Old Testament scholarship in South Africa- the next thirty to sixty years. I do not intend to simply rehearse the things that I mentioned at the OTSSA conference. I do build, however, on those initial thoughts. Therefore, this article will reflect on the present (where we are), the past (where we have been), and the future (where we are going) of Old Testament scholarship in South Africa.

However, let me make a disclaimer at this point. Any attempt to describe Old Testament scholarship in South Africa is relative, as it is impossible to follow all the trails. We cannot ride the wagon of pseudo-objectivity that assumes that history can be formulated from a God's-eye view. The dominance of certain trails does not negate the existence of other trails. As Gericke (2018:299-322) also highlights, historical overviews tend to take different research contexts and formats. Gericke identifies about 
thirteen types of historical overviews of Old Testament scholarship in South Africa, which have been done over the years. ${ }^{1}$ There are other areas to be explored, such as the following:

- The teaching of the Old Testament outside of the mainstream academic institutions. In this case, the focus would be in private or church-run Bible schools, Bible colleges, and theological seminaries;

- The development of Old Testament scholarship within the historically black universities;

- An overview of books which have been published by Old Testament scholars in South Africa over the past thirty-three years;

- The development of specialist groups in the study of the Old Testament in South Africa;

- The contribution of black South African Old Testament scholars to the field pre-1994 and post-1994.

This article is structured as follows: First, I reflect on second-generation Old Testament scholarship in South Africa with particular interest in the retirement of scholars as marking the end of an era. Second, I focus on the developments in black Old Testament scholarship as a trail which in some sense developed alongside white Old Testament scholarship. Third, I reflect on the prospects of Old Testament scholarship from a decolonial perspective.

\section{Second-generation Old Testament scholars in South Africa coming to an end: Is white dominance also coming to an end?}

\section{Second-Generation Old Testament Scholars}

Hendrik Bosman, towards the end of an article in which he reflects on Old Testament scholarship since 1994, asks the question: "Who are OT or HB scholars in South Africa"? (Bosman 2015:647) However, because he does not answer this pertinent question, I will attempt to answer it, whether directly or indirectly.

What better place to start than with Jurie le Roux's monumental work, A Story of Two Ways: Thirty Years of Old Testament Scholarship, which covers the period 1957-1987

Gericke classifies the historical overviews under the following categories: 1) large-scale studies of a distinctive period in the history the Old Testament Society of South Africa (Jurie H. le Roux), 2) critical appraisals or corrective and justifying responses to Le Roux's analysis (James A. Loader, Jurie H. le Roux); 3) subsequent supplementation to Le Roux's analysis in number 1 (Hendrik L. Bosman); 4) local reflection on exegetical methods (Ferdinand E. Deist, and Alphonso Groenewald); 5) local perspectives on a particular theme/approach (Willie S. van Heerden); 6) a particular scholar's contribution (Hans J. M. van Deventer); 7) critical comparisons of scholarly contributions (Christo Lombaard); 8) Old Testament scholarship vis-à-vis other theological disciplines (Wentzel J. V. van Huyssteen and Izak J. J. Spangenberg); 9) Old Testament scholarship at particular universities (Andries P. Breytenbach, Andries Breytenbach and Jurie H. le Roux, Jurie le Roux, and Dirk Human et al.); 10) Old Testament interpretation in particular church traditions (Ferdinand E. Deist, and Herrie F. van Rooy, and Marius Nel); 11) the Old Testament or Bible in the whole of Africa (Knut Holter); 12) Western perspectives' irrelevance to African concerns (Madipoane M. Masenya and Hulisani Ramantswana); and 13) perceived fallacies in contextual African perspectives (Christo J. S.

Lombaard, and Esias E. Meyer). 
and in which he reflects on Old Testament scholarship in South Africa? (Le Roux 1993). This range of years was chosen because 1957 was the year that the Old Testament Society of South Africa was established, and 1987 was chosen so that the range would be thirty years (Le Roux 1993:11). During this period, as Le Roux notes, Old Testament scholars produced an immense number of books, theses and articles (Le Roux 1993:11). My interest is in the historically marginalised black people of South Africa, but as I perused A Story of Two Ways, it became apparent that there was not one single reference to a black Old Testament scholar except C. S. Mngadi whose Master's thesis was written under the supervision of Professor Jasper J. Burden at the University of South Africa (UNISA).

In Le Roux's (1993:11-12) view, at the time, the thirty years period was what may come to be referred to as the golden era of Old Testament scholarship in South Africa. However, if the period has to be referred to as the golden era, it was the golden era of white Old Testament scholarship in South Africa as practised in the historically white Afrikaans and English universities. While UNISA as a distance learning institution accommodated black students, the staff of the Old Testament department was white. The same situation prevailed in all the other historically white universities as well. Therefore, as we shall see below, A Story of Two Ways is a one-sided and biased telling of a story that completely ignores black Old Testament scholarship in South Africa.

The so-called "golden era" in Old Testament scholarship was an era of white dominance that thrived under the colonial-apartheid regime. For example, in 1983 at UNISA, the Department of Old Testament had fourteen lecturers, who were all white (Burden 1983: iv-vii). ${ }^{2}$ The number of lecturers at the Department continued to grow over time. Except for the respective size of each of the departments, the situation at other Afrikaans universities was no different - the Old Testament scholars where all white. However, when Le Roux wrote A Story of Two Ways, the wind of change was blowing over South Africa, and therefore, he contemplated the future in the follow words:

The thirty years may well be described as the flowering of Old Testament in South Africa. Economic developments and social circumstances created job opportunities which allowed many a young scholar to enter the academic life. These events had, of course, far reaching consequences for the study of the Old Testament in South Africa. A younger generation now had the opportunity of devoting their lives to a study of the Old Testament. With enthusiasm they set themselves to their task and accomplished much over many years. In the long run they have contributed to the growth and development of an exegetical and theological tradition. Before that time this was impossible. A limited number of theological faculties, to which only a few Old Testament scholars were attached existed. These lecturers had to teach the whole field of Old Testament study leaving very little time for research and publication. Present-day South African Old Testament scholars must always keep those who carried the burden under difficult circumstances in high esteem. But it was the generation of the sixties, the seventies and the eighties who had the

2 These were Professors: J. J. Burden, F. E. Deist, and J. A. Loader; Associate Professor: Jurie le Roux; and Senior Lecturers: Joan Annandale, H. L. Bosman, and W. J. Wessels; and Lecturers: E. H. Scheffler, W. A. G. Nel and P. J. van Dyk; Junior Lecturers: J. A. Burger, J. P. H. Wessels; C. L. van W. Scheepers and Dalene Heyns. 
privilege of contributing to and enjoying the fine fruits of a flourishing South African science of the Old Testament. South Africa is, however, now standing on the verge of radical and far-reaching social and political change. These events will certainly cause dramatic changes to the university system and the nature of its staff. The possible lowering of standards and the adaptation of courses in order to address the grave social and economic needs of Africa may endanger the good work of the past thirty years. Radical changes may lead to the lack of a second and a third generation to continue the progress of the past three decades (le Roux 350-351).

In the words above, I cannot help but sense some fear and pessimism in le Roux at the time he wrote. The changing political dynamics in the country were not viewed positively. Basically, the white fear was that the looming takeover politically by the black people could undo the good work that Old Testament scholars had accomplished in the thirty years. Moreover, it was possible that there would not be a second or third generation of Old Testament scholars.

Thirty-three years later, Old Testament scholarship is still alive and well. The second generation indeed continued the progress of the first generation. What was feared is what the Vhavenda people refer to as $u$ ofha swiswi li sina phele (fearing the dark in which there is no hyena), which means that sometimes we tend to fear what we have no reason to fear. The young scholars in the 1980s and early 1990s were the second generation of scholars to carry the baton forward, and for most of them, the journey in academia is coming to an end with mandatory retirement. This includes such scholars as Jurie le Roux, Herrie van Rooy, Hendrik L. Bosman, Willie A. G. Nel, Sakkie Spangenberg, Coenie Scheepers, Eben Scheffler, Peet van Dyk, Willie Wessels, Phil Botha, Fanie Snyman, Gerald West, and Willem S. Boshoff. I include Jurie le Roux in the list of the second-generation scholars though his career spans from the middle of the first generation era, beginning in 1971 to 2006 when he officially retired. In him, the first generation lives on and the second generation draws its inspiration. It comes as no surprise that several scholars have reflected on his scholarship over the years. Apart from the OTE Festschrift 19/3 (2006), which was dedicated to Jurie le Roux, see particularly Human (2006):801-819; Gericke (2013:1-6); Bosman (2013:1-8); Lombaard (2006b:912-925; 2019); and Scheffler (2019:1-9).

Do we have to look at the recent spate of retirement as a sign of the coming to an end of an age? In my view, the ongoing retirements signal the coming to an end of the second generation of Old Testament scholars in South Africa. Retirements in general have the potential to bring down an academic unit or discipline where there is poor planning for succession. This may also result in the phasing out of this academic discipline as it may become absorbed in other disciplines with no unique identity of its own. In some instances, the mass retirements may result in the institution offering incentives to its retiring staff in order to continue to benefit from their experience. However, delaying retirement or offering contracts to the retired also has the potential of straining departmental budgets, especially in underfunded departments. Keeping retired people in the system may also amount to reducing job opportunities for upcoming scholars and disadvantaging minority groups, which may eventually have negative effects on the academic discipline (Bahrami 2001:297). In other instances, mass retirement may also result in mass hiring, which will eventually lead to another crisis down the line, thirty to 
forty years later (Ummersen, McLaughlin \& Duranleau 2014; cf. Foxall et al. 2009:172175).

In the case of UNISA, the mandatory retirement of seven scholars in the past four years has not resulted in the mass hiring which happened in the 1980s. In addition, it has not decimated the Old Testament unit at UNISA considering the number of scholars in other comparable institutions (Table A).

\begin{tabular}{|l|l|l|l|}
\hline \multirow{2}{*}{ Institution } & \multirow{2}{*}{$\begin{array}{l}\text { Number } \\
\text { of OT/HB } \\
\text { Scholars }\end{array}$} & \multicolumn{2}{|l|}{ Racial Profile } \\
\cline { 3 - 4 } & 8 & White & Black \\
\hline University of South Africa & 6 & 4 & 4 \\
\hline University of Pretoria & 2 & 5 & 1 \\
\hline University of Johannesburg & 2 & 2 & 0 \\
\hline University of North-West & 9 & 6 & 3 \\
\hline University of KwaZulu-Natal & 2 & 2 & 0 \\
\hline University of Free State & 5 & 4 & 1 \\
\hline Stellenbosch University & 6 & 5 & 1 \\
\hline University of Western Cape & 2 & 1 & 1 \\
\hline University of Fort Hare & 1 & 0 & 1 \\
\hline \multirow{2}{*}{ TABuE A } & 41 & 29 & 12 \\
\cline { 2 - 4 }
\end{tabular}

TABLE A

The profile of Old Testament scholars at the different South African universities shows that $^{3}$ UNISA currently has eight permanent staff members: Elelwani B. Farisani, Ig Gous, Magdel le Roux, Madipoane Masenya, Ndikhokhele Mtshiselwa, Gerrie Snyman, Schalk W. van Heerden and Hulisani Ramantswana. The University of Pretoria has six: Dirk Human, Sias Meyer, Alphonso Groenewald, Ananda Geyser-Fouche, Gerda de Villiers, Gert T.M. Prinsloo and Charlotte Sibanyoni. North-West University has nine stationed at different campuses: Albert Coetsee, Chris van der Walt, Lekgetho Moretsi, At Lamprecht, Gideon Kotze, Godwin Mushayabasa Murhiyashe, Hans van Deventer, Jaco Gericke and Lerato Mokoena. The University of Free State has five: Loedewyk Sutton, Marius Terblanche, Cynthia Miller-Naude, Jacobus A. Naude, and Tshokolo J. Makutoane. Stellenbosch University has five: Juliana Claassens, Louis Jonker, Ntozakhe Cezula, Christo van der Merwe, Alexander Andrason, and Izak Cornelius. University of KwaZulu-Natal has two: Helen Keith van Wyk and Charlene van Der Walt. ${ }^{4}$ The University of Johannesburg has two: Hennie Viviers and Gudrun Lier. Lastly, the University of the Western Cape has two: Tiana Bosman and Sarojini Nadar. ${ }^{5}$

The reduction in the number of scholars at UNISA implies that the dominance that UNISA used to enjoy in terms of numbers is waning, and soon it will no longer enjoy it. Therefore, scholars at UNISA are standing on shifting ground, as the University of

Old Testament scholars are also found in departments such ancient languages (UP, NWU, SU) and Bible Translation (UFS).

Charlene van Der Walt is appointed Associate Professor in the Gender and Religion discipline at UKZN.

Sarojini Nadar is currently serving as the Director of the Desmond Tutu Centre for Spirituality and Society within the Department of Religion and Theology. 
North-West may become dominant considering its structure, which allows it to offer programmes at the different campuses and therefore expand even its theology training.

Too many retirements may threaten the viability of an academic discipline. However, in the case of Old Testament scholarship in South Africa, retirements at UNISA do not necessarily reflect the trend in other public universities. The declining number at UNISA does not necessarily imply that the Old Testament discipline is dying, but it may be symptomatic of the challenge that lies ahead. Already, the general disconnection of biblical languages from the theological training programme was a blow to Old Testament studies. ${ }^{6}$ Most of the retiring Old Testament scholars, if not all, were also equipped with biblical languages, and this implies the vanishing of those skills within the discipline. In the current situation, there are people who hold doctorates in both Old Testament and New Testament without grounding in biblical languages. This is not to belittle those who have their doctorates without knowledge of the biblical languages, nor is it to blame the student; it is simply a reflection on the present situation. Perhaps the blame should be on those who leave the system without finding models of transferring rare skills and knowledge which are crucial for the discipline to continue to operate at present levels or at the higher level it needs to compete with its global peers.

In our current South African context, is it necessary, after over twenty-six years of democracy, that we should still bother about the racial profile in our institutions or departments? It may be that in other departments and disciplines, the issue of transformation has become a non-issue; however, considering the history of apartheid and the lingering ugly head of racism, it is necessary to also consider the racial profile of Old Testament scholars. Old Testament scholarship in South Africa's public universities is still pretty much a white-dominated discipline. This white dominance cannot simply be traced back to the hiring in the 1980s and the 1990s; it also reflects the continuing hiring trend in our universities, which favour the minority whites. Old Testament scholarship in South Africa has not done enough to produce a pool of black scholars. Is it not embarrassing that in the current dispensation, representation of black scholars is still lower than that of the whites (eleven blacks versus twenty-nine whites)? Furthermore, for almost thirty years, the black female voices of Madipoane Masenya (Ngwan'a Mphahlele), Sarojini Nadar, and Makhosazana K. Nzimande (who entered the scene for just a short while) were the only black female voices in Old Testament scholarship - compared to white female voices in the same period, among whom are Joan Annandale (or as also known Joan Annandale-Potgieter), Dalene Heyns, Frances Klopper, Helen Efthimiaded-Keith (also known as Helen Keith-van Wyk), Magdel le Roux, Julie Claassens, Gerda de Villiers, and Charlene Van der Walt. The recent appointment of two black females, Charlotte Sibanyoni as a lecturer of Hebrew at UP and Lerato Mokeona at North-West University (Mahikeng Campus), is a positive addition. However, these two and others belong to the emerging third generation of scholars that I will refer to subsequently.

\footnotetext{
$6 \quad$ We do sit with students who wish to pursue Old Testament or New Testament studies at postgraduate level without knowledge of biblical languages, but we need to begin to require of those who work within the biblical disciplines to demand of their students to take some basic Hebrew and/or Greek. Therefore, it is also incumbent on biblical scholars of the Old and New Testament to find ways to get the students to learn biblical languages, be it as short learning courses or as additional modules during the undergraduate years as part of requirements for specializing in these areas.
} 


\section{Legacy of the second generation of Old Testament scholars}

An emerging trend in the last three decades is the development of multiple specialist areas in Old Testament study in South Africa. This move has to do primarily with the scholars' area of interest, which has led to the emergence of focus groups or specialist groups. In the academia, specialisation is justified by the argument that it is impossible of any one person to be an expert in more than one area - a narrowing that is satirized as, one "knows more and more about less and less" (Shipman \& Shipman 2016). It should be noted, however, that areas of specialisation do not remain static. As Jenniskens and Morphew (1999:95-120) note, "scholars' interests evolve, students' needs change, and the external environment shifts as well". Unfortunately, specialist groups/focus areas tend to breed disciplinary silos and this situation encourages scholars to limit their research to the scope of their area of interest or specialisation (Cohen \& Lloyd 2014:196). The existence of specialist groups does not imply that scholars simply stick to their group and cannot contribute to other groups. Considering the pool of Old Testament scholars in South Africa, it is only logical to expect that such crosscontributions in the different areas would be there, howbeit from the different perspectives of scholars who are not necessarily specialists in the group.

Specialist groups have also been enriched through collaboration with international scholars from across the continent of Africa, Europe, and the USA. The appointment of extraordinary professors in universities, the invitation of guest lecturers, and the appointment of research fellows/associates who publish with our institutions are indicative of the collaboration and networking which Old Testament scholars engage in to develop the discipline and their respective areas of specialisation. The current climate in South African public universities fosters collaboration and networking by providing room for such appointments to boost their research output. Furthermore, the National Research Foundation with funding instruments such as the Knowledge Interchange Collaboration (KIC) fosters collaboration and knowledge exchange between scholars.

Various areas of specialisation have developed in the last three decades, some of which I will simply mention without going into details. The areas include Pentateuch (Pro-Pent), Psalms (Pro-Psalms), Prophets (Pro-Prophets), Eco-theological, Trauma, Feminist/Womanist, Spirituality, Philosophy of religion, Hermeneutic of vulnerability, Chronicles, Ezra-Nehemiah, Exilic and Post-exilic periods, Second Temple period, Septuagint studies, African biblical hermeneutics and Decolonial readings (Bosman 2015:636-654; Gericke 2018:299-322). The existence of multiple areas of specialization in Old Testament scholarship advances the scholarship, and we ought to remain open to venturing into new areas to be at the cutting edge of Old Testament scholarship. However, as Bosman warns, we should also "reflect on the impact and legacy" which our research will have in the future.

The second generation of Old Testament scholars is still pretty much white dominated and so hands over to the third generation a scholarship that has started to transform but has not yet fully transformed. Therefore, it is incumbent on those of the third generation to ensure that Old Testament scholarship continues to be blackened. This, however, will require targeted intervention, such as identifying potential students and nurturing and developing their interest in Old Testament studies. For example, I, in part, owe my interest in the Old Testament to my undergraduate Hebrew lecturer, Jan Kroeze, and my emeritus professor, Herrie van Rooy, who nurtured in me the love of Semitic languages 
as well as the Old Testament/Hebrew Bible. What is needed now is to intensify such efforts - by showing the relevance of Old Testament study to our students. The common perception among theology students preparing for ministry is that disciplines such as missiology, spirituality, practical theology, and systematic theology or dogmatics are more relevant to ministry than disciplines such as Old Testament and New Testament.

\section{From the margins: Black Old Testament scholarship}

During the colonial-apartheid period, black scholarship had to operate in the margins. In 1959, the apartheid government passed the Extension of University Education Act, which banned blacks from receiving higher education at the same universities as whites. This act, as Badat (1999:50-51) notes, was intended to "arrest and reverse" the developing situation in which blacks received higher education at the same institutions with whites, particularly the white English-language universities. ${ }^{7}$

This act also laid the foundation for the establishment of black universities and colleges, specifically, University Colleges of the North, University of Zululand, University of the Western Cape, and University of Durban (later, University of DurbanWestville). The apartheid policy at the time required that such institutions be established in the "Native areas", away from the white urban centres (Rose \& Tunmer 1975). ${ }^{8}$ The education minister of the apartheid regime had the responsibility to appoint senior academic and administrative staff. As Balintulo points out, the modus operandi was "to appoint their own men, some of the recent graduates, invariably from the Afrikaansmedium universities, and promote them rapidly" (Balintulo 1981:150). Badat (1999:71) further notes that, "Liberal senior administrators and academics were fired and repressive measures like a ban on staff engaging in political activity resulted in resignations". The academic positions at black universities were dominated by whites, especially at professor and senior lecturer levels.

In line with the Extension of University Education Act, churches also continued to establish separate theological schools or seminaries for the training of blacks. In most of the black seminaries, training was mainly in the hands of the whites. Most of the black theological schools were established by white churches for the training of the black-it was their school for them, and so the Afrikaans saying, "ons skool vir hulle". Ntwasa (1972:179), reflecting on the situation of black students at the seminaries at that time, wrote,

The problems do not end here in the white staff/black student seminary situation. The white staff are frequently highly competent academically judged by the standards and requirement of Western universities. None of them, however, have any existential knowledge of what it is to be a black man in a white racist South

Prior to the 1959 Education Act, higher education for black students was focused mainly on teacher training, which was carried out at teacher-training institutions, some of which were run by churches. The teachertraining institutions were initially a continuation of secondary education. Prior to 1948, a higher teaching diploma was offered at the South African Native College, which became Fort Hare University. Some of the black students, however, gained access to English universities such as the University of Cape Town, University of the Witwatersrand, University of Natal, and the University of South Africa. The Afrikaans universities, however, did not admit black students. I am indebted here to Badat (1991:47-75).

8 The black universities initially had the status of colleges and therefore awarded degrees from UNISA. It was only in 1969 that these universities started to function as fully-fledged universities. 
Africa. This makes it impossible for them to think theologically from the basis of this human experience common (in varying degrees) to all South African blacks. This is bad enough, but it is still not all. Few, if any, of them have any first-hand experience of either black communities or parishes in their living or work situation. Those who do not come from overseas to the seminaries have experienced South Africa from the situation of the white suburbs.

The black theological students who wanted to continue with their education at postgraduate level had to do so at the white universities (Afrikaans or English) or go abroad. Desmond Tutu went to further his studies in London at King's College, where he obtained his Master of Theology in 1966. Manas Buthelezi did his postgraduate studies in the USA at Drew University, where he obtained his PhD in Systematic Theology in 1968. Allan Boesak obtained his PhD at Kampen Theological Institute in the Netherlands in 1976. Ephraim K. Mosothoane obtained his PhD at the University of Aberdeen. Barney Pityana, while in exile in London, studied theology at King's College London and at Ripon College Cuddesdon. Ntwasa (1972:180) reflecting further on the training of black students, notes that,

At the moment it would be unfair to say that the most positive contribution our seminaries have been able to make is that they have enabled students to be sufficiently competent to study abroad (in white Western academic institutions). These students can study the Bible in the original languages and learn something about church history, the historical debates on doctrine, and doctrine itself. But as creative agents for change in South African church embedded in the South African socio-political situation they have largely failed.

While the scholars listed above did not earn PhDs in Old Testament, it is worthwhile to note that when Desmond Tutu joined the staff at Federal Theological Seminary, he taught Old Testament among other modules.

It was not the $\mathrm{PhD}$ degrees which qualified blacks to engage in critical reflection on the Old Testament; rather, they were qualified by their existential situation of damnation. It was in the context of the struggle for human dignity, justice, life, and land that they started theologizing from the Old Testament. As Ntwasa (1972:181) argues,

If the Christian gospel is about liberation from sin, then it is not simply from individual, personal, private sins (like swearing and fornication) but also about liberation from the social sins which dehumanize and debilitate people (especially black people in South Africa). The vast majority of our black people suffer shockingly under the impact of racism but poverty, hunger, ignorance and disease. The problems of most of our people are immediate bread and land issues.

Black scholars began to publish in outlets such as the Journal of Theology for Southern Africa, Pro Veritate, Reality and Missionalia. For black theologians in South Africa in the 1960s to the 1980s, the study of the Scriptures could not be divorced from the lived experience of the black masses. Theirs was not a theology enclosed in the ivory towers of academic institutions; rather, it was a theology of liberation, and the Old Testament 
played a central role in their theologizing. Of particular concern in reading the Old Testament was the issue of social justice. Therefore, there was emphasis on the creation of all human beings in the image of God, the theme of liberation (exodus motif, YHWH as a liberator, and YHWH being on the side of the oppressed), and the call for a just society (YHWH as God of justice and relating acts of injustice in the biblical text and today's context). For example, West (1995:64-66) points out that Boesak's biblical hermeneutics utilised three interpretive procedures: First, he read the biblical text in the context of the struggle of black people of South Africa. Second, he linked the struggles in the text to the struggles in the here and now, thereby advocating for a shared or common humanity. Third, he focused on the final form of the text-reading the texts as self-contained and yet as part of the broader canonical story, which finds its culmination in the person and works of Jesus Christ (see also Boesak 1977; 1984).

In the ivory tower of white Old Testament scholarship, an outlet such as Old Testament Essays, of which I am the current editor, was in the 1980s a product that served white scholarship, whose publications did not speak to the reality of the black masses. The first publication by a black South African Old Testament scholar in Old Testament Essays was in 1991. The article, "In the School of Wisdom: An Interpretation of Some Old Testament Proverbs in a Northern Sotho Context", was written by Madipoane J. Masenya. I return to Madipoane Masenya (Ngwan'a Mphahlele) shortly.

Flint, in his "Old Testament Scholarship from an African Perspective" (1986), notes that only few black Old Testament scholars were found in South Africa, and he could only identify two, namely, E. K. Mosothoane, a lecturer at a black university, the University of Transkei, ${ }^{9}$ and C. S. Mngadi, a senior lecturer (Old Testament) at the University of Zululand. Mngadi obtained his master's in theology at the University of South Africa in 1982 with a thesis entitled "The Significance of Blood in the Old Testament Sacrifices and its Relevance for the Church in Africa". Mngadi would later serve in the editorial board of Old Testament Essays. What is significant about these scholars is that they engaged in Old Testament scholarship from the margins.

It is quite unfortunate that, when black universities were established, departments of theology or religion were not entrenched in the systems of those institutions. Today, theology departments and faculties of theology exist in only a few of the historically black universities in South Africa-University of the Western Cape and the University of KwaZulu-Natal, which is the product of the merger between University of DurbanWestville (historically black) and University of Natal (historically white, with a medical school for blacks). This, in turn, implies that biblical studies (Old and New Testament) could not gain a foothold at academic institutions in the margins. In the current context, it is difficult to say whether there is room to revive some of those departments in the historically black universities, considering that the field of theology or religion does not necessarily draw large numbers of students.

While Flint in 1986 could only identify two black Old Testament scholars, the ground was shifting. Two others emerged in the 1980s and early 1990s-Itumeleng Mosala and Madipoane Masenya (Ngwan'a Mphahlele). To these two I turn attention.

9 In my view, Prof Mosothoane was more of a historical theologian, and some of his works tended to focus on the New Testament rather than the Old Testament. 
Itumeleng Mosala: 1987 and the rise of Black Theology Old Testament scholarship

While 1987 marks the end of the first generation of white Old Testament scholarship, from a black perspective the same year should be viewed as a monumental year in black Old Testament scholarship That year, Itumeleng Mosala completed his $\mathrm{PhD}$ at the University of Cape Town with a dissertation entitled, "Biblical Hermeneutics and Black Theology in South Africa", which was published in $1989 .{ }^{10}$ I can safely say that Mosala's book contributed immensely to shaping the hermeneutics of subsequent black theologians in South Africa. Not only did his book become important to black Old Testament scholars, its influence cuts across theological disciplines, particularly in the following ways.

First, it marks a hermeneutical shift among black theologians in South Africa. Mosala saw the need for black theologians to "break ideologically and theoretically with bourgeois biblical hermeneutical assumptions" and be theologically well grounded. The Bible, for Mosala, does not have to be viewed as an innocent book which contains the "Word of God" and therefore does not have to be critically scrutinised. The Bible in Mosala's hermeneutic should be viewed as a human product tainted by oppressive ideology.

Second, the primary concern for black theology of liberation should be the struggles of the black masses. For Mosala (1986:120b), "Black Theology has roots in the Bible in so far as it is capable of linking struggles of the oppressed people in the communities in the Bible". Therefore, black theology has to be rooted in "black history and culture in order for it to possess apposite weapons of struggle, that can enable black people to get underneath the biblical text to the struggles of the oppressed classes".

Third, the Bible has to be analysed using historical-critical tools. This is important so that the biblical texts can be understood in their own contexts. As West (2016:334) notes, the interpreter needs 'to identify and delimit the 'sources' that underlie the final canonical form of the text and then to historically locate those source texts within a particular time and place". Mosala (1989:29) also writes that, "A century of historicalcritical scholarship has demonstrated beyond any doubt that the Bible is made up of a multiplicity of varying and often contradictory traditions that are a function of both a long history over which they have been produced and a variety of situations that produced them".

Fourth, the interpreter has to pay attention to the materialist and ideological conditions of the text, and by so doing, investigate the world behind the text, the class struggles in ancient Israel and the ideologies of those who composed the biblical texts. The materialist struggles in ancient Israel are in this case analysed from a Marxist perspective, which pays attention to the different classes in society and the modes of production. The ideological component considers the class struggle behind the text and the class interests in the text as it stands.

Fifth, the interpreter draws an analogy between the class struggles in the present-day context and those struggles that lie behind the biblical text. While Mosala agrees in principle with the analogical method of the other black theologians, his focus was

10 Prior to 1987, Mosala had published several works including Mosala (1985; 1986a; 1986b; 1986c; 1986d; 1986e). 
different. Whereas other black theologians such as Tutu and Boesak focus on the struggle as projected by the text (or in the text and in front of the text); for Mosala, the focus is on the struggles behind the text which can be understood through a historical-materialist analysis of the text (West 1995:74-75).

The central contribution of Mosala is in providing the hermeneutical foundation, which helped to shape the second phase of Black Theology (West 2016:329-330). The work of Mosala should not simply be located within black theology; his study fits within the scope of biblical or Scripture studies. Although the book has a canonical focus, it can rightly be claimed as a monumental work in black Old Testament scholarship. Therefore, it is incumbent on black scholars to build on the foundation that Mosala laid as an excellent builder. He can rightly be regarded as the ntate/khotsi/baba (father) of black Old Testament scholarship.

\section{Madipoane Masenya: Female voice centring the struggles of African women and the African knowledge system}

The first black female voice in South African Old Testament scholarship is that of Madipoane Masenya (Ngwan'a Mphahlele). Masenya developed a unique approach to reading the Bible, which she calls bosadi (1992:271-287; 1996; 1997a:55-68; 1997b:1516; 1997c:439-48). Her voice began to rock the boat of white Old Testament scholarship as it emerged within a white-dominated Old Testament department at UNISA. Masenya's work is significant for Old Testament scholarship from the following fronts.

First, it brings to the centre the experiences of African women in the theological enterprise. Masenya's bosadi approach is significant in this regard, as she affirms, "I deliberately make my African-South African sisters' context the main hermeneutical focus" (Masenya 2005a). On the concept of bosadi, Masenya (2005b:183) explains,

Reclaiming the use of the Northern Sotho word bosadi not only makes sense to African-South African women at the grassroots level, women with whom I interact constantly and thus, naturally, it also succeeds in enabling these women to read the Bible in that affirms them, because the bosadi approach acknowledges the uniqueness of the context of African-South African women.

The bosadi approach demands the centring of African women's struggles in the reading of the biblical texts-it is a reading from the perspective of a woman/mosadi. The "African" aspect is important and Masenya (2015:68-79) takes Africa as a hermeneutical focus in her approach.

Second, for Masenya, the Bible is not an innocent book; rather, its ideology projects both degradation and affirmation of women. While the Bible is a book of faith, it does not follow that ideologies in the text that are oppressive to women must be uncritically accepted. In the bosadi approach, thus, the patriarchal nature of biblical texts is not ignored; rather, it is critically engaged.

Third, in Masenya's interpretation, African cultures are also not innocent. The patriarchal tendencies in our cultures have to be confronted and negated. Therefore, the bosadi approach reflects on the conditions of basadi or women in the current context and challenges the life-denying realities that women face. 
Fourth, Masenya utilises African knowledge systems to read biblical texts. Although she often uses African proverbs as lenses through which to engage critically with the biblical text, her approach is not limited solely to the use of proverbs. Other knowledge systems and life experiences such as HIV/AIDS, racism and xenophobia are also appropriated and utilised in reading the biblical texts.

Where there is a father, there should also be a mother. Therefore, I contend without fear of contradiction that Madipoane Masenya (Ngwan'a Mphahlele) is the mma/mme/mama ("mother") of black Old Testament scholarship in South Africa. It was by drinking her sweet African milk that some of us grew as Old Testament scholars, as she taught us to value our cultural elements in our engagements with biblical texts. Furthermore, it was under her wings that I learned the trade of scholarly publishing as one who had a mother to guide him. Through her, we learned anew the beauty of our African proverbs.

There are those like Lombaard (2006a:144-155) who contend that there is nothing particularly African in the approaches that have been developed by African biblical scholars. The idea that the approaches developed by our black theologians are merely contextual should be viewed as reflecting a mindset which tends to view the Western approaches as the standard. Pace Lombaard, the community of faith and the people in our country are not better served when what we engage in remains an elitist endeavour in the corridors of academia. Rather, the community of faith and the people are best served when our scholarship speaks to and helps provide solutions to our people's needs.

\section{The decolonised future of Old Testament scholarship in South Africa}

Snyman (2016:99), reflecting on the future of Old Testament scholarship in South Africa, declares that, "Old Testament scholarship in South Africa is in a unique position by being the meeting ground for African approaches to the Old Testament as well as the traditional Western approaches. It is not a matter of either/or, but rather a matter of both/and". This option may have its appeal, but as a black Old Testament scholar, I approach the matter from a different perspective. The challenge for African biblical scholars is to delink from the Euro-Western paradigms and start thinking outside them. To transcend Euro-Western paradigms, it is crucial to approach the Old Testament from the perspective of colonial difference. Pertinent for black Old Testament scholars is to recognize the provinciality and limitations of Euro-Western paradigms and to choose to liberate our minds and practice our scholarship outside of the confines of the Western hermeneutical practices.

Therefore, in envisioning the future, I propose the following.

\section{The third generation of Old Testament scholars should be a decolonised generation}

A decolonised future requires resistance to the notions of racial superiority and knowledge superiority. The story of two trails should evolve as the two trails merge and we build a decolonised Old Testament scholarship. Black Old Testament scholars no longer have to see themselves as the accommodated other in a white guild. White Old Testament scholars, on the other hand, have to work with black scholars as their equals. The third generation has to be different, and I would like to believe that things will be 
different. We can make things different as we work together to build Old Testament scholarship in South Africa.

The third generation already incorporates black scholars such as Charlotte Sibanyoni, ${ }^{11}$ Lerato Mokoena, Ndikhokhele Mtshiselwa, Hulisani Ramantswana, Lekgetho Moretsi, Ntozakhe Cezula, Lehlohonolo J. Bookholane, and Tshokolo J. Makutoane. Included also in the list are the following scholars from other African countries who are establishing their roots in South Africa: Funlola Olojede, Sampson S. Ndoga, Godwin M. Mushayabasa, and Daniel Simango. Therefore, it is in joining hands with white scholars such as Sias Meyer, Ananda Gyser Fouche, Alphonso Groenewald, Charlene van der Walt, Helen Keith-van Wyk, Jaco Gericke, Gideon Kotze, Albert Coetsee, Chris van der Walt, Marius Terblanche, and Lodewyk Sutton, as well as those who will join in this generation, that we can build a better future for our discipline.

In my view, because scholars such as Elelwani Farisani, Juliana Claassens, Louis Jonker, and Hans van Deventer emerged at the midpoint of the second generation, they should anchor, so to speak, the third generation of scholars. Therefore, they have great responsibility on their shoulders. As a way of passing the baton in the practice of their scholarship, scholars must shift gear to strengthen the next generation. Just as Jurie H. le Roux functioned as a link between the first and second generations, these scholars also have a role to play in strengthening the third generation of Old Testament scholars.

However, as the baton is passed, we cannot ignore the reality of our South African context. Black people are the majority, and this need to be reflected in our scholarship. The historically white institutions are blackening, and they will continue to blacken irreversibly and irresistibly. The more they blacken, the more they will also require black scholars.

\section{Production of Old Testament theology from the (South) African perspective}

In his recent article, "Mapping Recent Development in Old Testament Theology", Snyman (2019) presents a historical overview with a focus on developments in Old Testament theology in the twentieth and twenty-first centuries. However, his conclusion notes two things among others:

Women made huge and important contribution to the understanding of the Old Testament in recent decades in all fields of the study of the Old Testament, yet an Old Testament theology written by a woman has not been published.

Africa has not yet produced a theology of the Old Testament. This is a challenge to Old Testament scholarship in Africa. Although the study of the Old Testament is a vibrant part of the study of theology in general, Africa has not yet produced an Old Testament theology originating from African soil (Snyman 2019:7).

Snyman's challenge to African theologians to produce an Old Testament theology should be welcome, particularly, by those of us who belong to the third generation of

11 Having listened to her first presentation at the Old Testament Society of Southern Africa, I am hoping that she will not limit herself simply to teaching Hebrew language, but will also venture more into the study of the Hebrew Bible/Old Testament. 
Old Testament scholars. The more important question which we have to answer is whether such an Old Testament theology will be done through the Euro-Western lens or indeed be an African Old Testament theology. Therefore, we wait to see how this challenge will be answered.

\section{Reviving prophetic theology: Overcoming the disconnect with the masses}

The strength of our scholarship does not have to be simply in our writing for our peersthose in the scholarly guild. It is high time we wrote with the community in mind. Our scholarship has to target not only academic libraries, but also home libraries; we have to write for laypeople as well. In this way, our scholarship will help shape the ordinary people and those who are in ministry who require resources that speak to their context. In this way, we shall revive the Kairos Document's call for a prophetic theology:

To be truly prophetic, our response would have to be, in the first place, solidly grounded in the Bible. Our KAIROS impels us to return to the Bible and to search the Word of God for a message that is relevant to what we are experiencing in South Africa today. This will be no mere academic exercise. Prophetic theology differs from academic theology because, whereas academic theology deals with all biblical themes in a systematic manner and formulates general Christian principles and doctrines, prophetic theology concentrates on those aspects of the Word of God that have an immediate bearing upon the critical situation in which we find ourselves. The theology of the prophets does not pretend to be comprehensive and complete; it speaks to the particular circumstances of a particular time and place-the KAIROS (Kairos Document 1986; cf. Leonard 2010:63).

As third generation Old Testament scholars, our moment requires us to seek decolonial justice while considering the continuing structures of colonialism and apartheid, which continue to shape our society and subjugate us culturally, socially, politically, and economically. In seeking decolonial justice, our scholarship has to be prophetic as we engage with the masses. Furthermore, our scholarship has to engage the powers that be considering the corruption and the failure to improve the quality of life for the majority of our people on the part of the leaders.

\section{The blackening of Old Testament Society of South Africa and the shift to an Old Testament Society of Africa}

The future of Old Testament scholarship is in its blackening. The same also applies to sister societies such as the Society of Ancient Near Eastern Studies (SASNES) and the Association for the Study of the Septuagint in South Africa (LXXSA). If these societies do not become blackened, then, they will have to strengthen their bonds with Europe to survive - which will happen for some time, but they will die anyway. How is it that after six decades of the Old Testament Society of South Africa, blacks are still in the minority in a country that is predominantly black? As a young black Old Testament scholar who loves this discipline, I therefore have the right to ask, why have we failed to nurture the South African black child in our discipline? What has happened to the black child? Senzenina (What have we done)? What have we done that makes our presence invisible? I ask this question so that we can steer the ship in the right direction. The future of this 
discipline and the society lies in its production of black South African Old Testament scholars. Otherwise, the future is bleak.

The blackening of the Old Testament Society of South Africa should not be understood in exclusionary terms as though the blackening implies the exclusion of the other. The blackening of the society is a process of redress in a situation which was characterised by exclusion and discrimination. The blackening of the society amounts to the broadening of the society in a way that the society would reflect the continent in which it has to thrive. Thus, the decolonial turn will be incomplete as long as we do not move beyond the Old Testament Society of South Africa to an Old Testament Society of Africa, which would involve crossing boundaries and breaking down colonial boundaries. In that way, we further blacken Old Testament scholarship in Africa. What is currently known as the Old Testament Society of South Africa should in the future evolve to be a regional space. Our meeting place with fellow African scholars should not primarily be in Europe or the USA when we attend Society of Biblical Literature (SBL) or the International Organisation for the Study of the Old Testament (IOSOT), but here on the African soil.

As editor of Old Testament Essays, I am humbled by the article contributions that our journal receives from scholars across Africa. The publications of these scholars in Old Testament Essays point to the richness on the African continent and we can glean more from one another not simply through publications, but also through other engagements with one another. The poem by my sister, Muneiwa Ramantswana, rings in my head:

Africa my home

Africa our continent

Africa the place of ubuntu

Where black, white, and coloured are accommodated

Africa the home of many like myself

Many have landed on you, but many have left without a reason

$\mathrm{Oh}$ ! Africa the continent of the happy and sad - the poor and rich

Africa the continent where heroes and heroines are born every break of dawn

$\mathrm{Oh}$ ! Africa the continent with creative minds

Wake up! Child of Africa

The father calleth his son who seeketh shelter for the night

Many have for today's world

But many are no longer with us as we speak

Rise up! Daughters of the soil

The land awaits your hard work and prosperity

"Life and death in the soil", they say

Then why wait for the future generation to die of hunger

Why wait for the cattle to die without use

Vukani! Amadoda ne Bafazi

The world is in your hands

The rest look at you to bring out the map to success

Oh! Afrika die wêreld is ons s'n 


\section{Takalani nothe dzitshaka dza Afurika}

How many nations are there,

Nigerians, Zimbabweans, Zambians ...

They are so many, some we never know where they live and hibernate

A ri tsamaye Ma Afrika!

The journey can come to a halt at any time

Though some say the journey is too long, some say it is too short

There is one thing we stand for

Our vision is to fight poverty

Our prayer is to have a peaceful environment

To have harmony - the sweet perfume of friendship and unity

Oh! Africa my home, Africa, our continent (M. Ramantswana 2003:4-5).

\section{Conclusion}

Old Testament scholarship in South Africa is a story of two trails- the white trail and the black trail. I hope that members of the third generation of Old Testament scholars will embrace each other and work together to develop Old Testament scholarship. The immediate challenge that confronts us as South African Old Testament scholars is to train more black scholars. We fail to do this to the peril of our discipline.

\section{BIBLIOGRAPHY}

Badat, M. Saleem. 1999. Black Student Politics, Higher Education and Apartheid: From SASO to SANSCO, 1968-1990. Pretoria: Human Sciences Research Council.

Bahrami, Bahman. 2001. "Factors affecting faculty retirement decisions". The Social Science Journal 38: 297- 305.

Balintulo, M.M. 1981. "The Black Universities in South Africa". In Rex, J. (ed.), Apartheid and Social Research. Paris: UNESCO, 141-159.

Boesak, Allan. 1977. Farewell to Innocence: A Socio-ethical Study on Black Theology and Power. Maryknoll: Orbis.

1984. Black and Reformed: Apartheid, Liberation and Calvinist Tradition. Johannesburg: Skotaville.

Bosman, Hendrik. 2013. "The Historical Understanding of the Old Testament in South Africa: Colenso, Le Roux and Beyond". Verbum et Ecclesia 32 (2): 1-8. https://doi.org/10.4102/vev34i2.793.

2015. "Ants, Spiders or Bees... and Ticks? A Typology of Old Testament Scholarship in South Africa since 1994 within Its African Context". Old Testament Essays 28 (3): 636-654.

Burden, J.J. 1983. "Foreword". Old Testament Essays 1: iv-vii.

Cohen, Eli B., and Scott J. Lloyd. 2014. "Disciplinary Evolution and the Rise of the Transdiscipline". Informing Science: The International Journal of an Emerging Transdiscipline 17:189-215.

Foxall, Martha, et al. 2009. "Faculty Retirement: Stemming the Tide". Journal of Nursing Education 48 (3): 172-175. 
Gericke, Jaco. 2013. "J.H. le Roux's Philosophy of Religion". Verbum et Ecclesia 34 (2): 1-6. https://doi.org/10.4102/ve.v34i2.827.

2018. "The Concept of Philosophy in Post-Apartheid Western Historical Overview of South African Old Testament Scholarship". Old Testament Essays 31 (2): 299322.

Human, Dirk. 2006. "Jurie Hendrik le Roux: Deernisvolle Mens en Veelsydige Akademikus". Old Testament Essays 19 (3): 801-819.

Jenniskens, Ineke, and Christopher Morphew. 1999. "Assessing Institutional Change at the Level of the Faculty: Examining Faculty Motivations and New Degree Programmes". In Jongbloed, Ben W., Maassen, Peer A. and Neave, Guy (eds.), From the Eye of the Storm: Higher Education's Changing Institution.Dordrecht: Kluwer Academic Publishers, 95-120.

Le Roux, Jurie H. 1993. A Story of Two Ways: Thirty Years of Old Testament Scholarship in South Africa. OTE Supp 2; Pretoria: Verba Vitae.

Lombaard, Christo. 2006a. "The Relevance of Old Testament Science in/for Africa: Two False Pieties and Focused Scholarship". Old Testament Essays 19 (1): 144-155.

2006b. Teks en mens. JH le Roux se lees van die Bybel binne die Konteks van Hoofstroom-Ekseges in Suid-Afrika”. Old Testament Essays 19 (3): 912-925. 2019. "Non-Moses le Roux: Premises, Promises and Fulfilment in the Work of J.H. le Roux". Verbum et Ecclesia 40 (1), a1913. https://doi.org/10.4102/ve.v40i1.1913. Masenya, Madipoane J. 1991. "In the School of Wisdom: An Interpretation of Some Old Testament Proverbs in a Northern Sotho Context". Old Testament Essays 4 (2): 171-191.

1992. "A Bosadi (Womanhood) Reading of Genesis 16". Old Testament Essays 11 (2): 271-287.

1996. "Proverbs 31:10-31 in a South African Context: A Bosadi (Womanhood) Approach". Dlitt et Phil Thesis. Pretoria: University of South Africa.

1997a. "Proverbs 31:10-31 in a South African Context: A Reading for the Liberation of African (Northern Sotho) Women". Semeia 78: 55-68.

1997b. "Reading the Bible the Bosadi (Womanhood) Way". Bulletin for Contextual Theology in Southern Africa and Africa 4 (2): 15-16.

1997c. "Redefining Ourselves: A Bosadi (Womanhood) Approach". Old Testament Essays 10 (3): 439-448.

2005a. "Struggling to Find 'Africa' in South Africa: A Bosadi (Womanhood) Approach to Biblical Texts". SBL Forum, Online: http://sblsite.org/publications/article.aspx? articleId $=402$.

Masenya, Madipoane J. (Ngwan'a Mphahlele). 2005b. "Their Hermeneutics Was Strange! Ours Is a Necessity! Rereading Vashti as African-South African Women". In Stichele, Caroline V. and Penner, Todd (eds.), Her Master's Tools? Feminist and Postcolonial Engagements of Historical-Critical Discourse. Atlanta: Society of Biblical Literature, 175-194.

2015. "An African Methodology for South African Biblical Sciences: Revisiting the Bosadi (Womanhood) Approach". In Smith, Mitzi J. (ed.), I Found God in Me: A Womanist Biblical Hermeneutic Reader. Eugene: Cascade Books, 68-79.

Mngadi, C. S. 1982. "The Significance of Blood in the Old Testament Sacrifices and Its Relevance for the Church in Africa". MTh Thesis: UNISA. 
Mosala, Itumeleng. 1985. "African Independent Churches: A Study of in SocioTheological Protest". In Villa-Vicencio, C. and De Gruchy, J. W. (eds.), Resistance and Hope: South African Essays in Honour of Beyers Naudé. Cape Town: David Philips, 103-111.

1986a. "Black Theology versus the Social Morality of Settler Colonialism: Hermeneutical Reflections on Luke 1 and 2". Journal of Black Theology 1: 26-42. 1986b. "Ethics of the Economic Principles: Church and Secular Investment". In Thlagale, B. and Mosala, I. J. (eds.), Hammering Swords into Ploughshares: Essays in Honour of Archbishop Mpilo Desmond Tutu. Johannesburg: Skotaville, 119-129. 1986c. "Social Scientific Approaches to the Bible: One Step Forward, Two Steps Backwards". Journal of Theology for Southern Africa 55: 15-30.

1986d. "The Relevance of African Independent Churches and Their Challenge to Black Theology". In Mosala, I. J. and Thlagale, B. (eds.), The Unquestionable Right to Be Free. Johannesburg: Skotaville, 91-100.

1986e. "The Use of the Bible in Black Theology". In Mosala, I. J. and Thlagale, B. (eds.), The Unquestionable Right to Be Free. Johannesburg: Skotaville, 175-179.

1987. "Biblical Hermeneutics and Black Theology in South Africa". PhD Dissertation. Cape Town: University of Cape Town.

1989. Biblical Hermeneutics and Black Theology in South Africa. Grand Rapids: Eerdmans.

Ntwasa, Sabelo S. 1972. “The Training of Black Ministers Today”. International Review of Mission 61 (242): 177-182.

Ramantswana, Muneiwa. 2003. Africa My Home, Africa Our Continent. Malvern: umSinsi.

Rose, B., and R. Tunmer. 1975. Document in South African Education. Johannesburg: AD Jonker.

Scheffler, Eben. 2019. "Jurie le Roux: Master of Many Academic Trades". Verbum et Ecclesia 40 (1): 1-9, a1938. https://doi.org/10.4102/ve.v40i1.1938.

Shipman, Alan, and Marten Shipman. 2016. Knowledge Monopolies: The Academisation of Society. Exeter: Imprint Academic.

Snyman, S.D. (Fanie). 2016. "What Happened to the Prophets in South Africa since 1994"? In Rian Venter (ed.), Theology and the (Post)Apartheid Condition: Genealogies and Future Directions. Bloemfontein: Sun Media, 88-104.

2019. "Mapping Recent Development in Old Testament Theology". HTS Teologies Studies/Theological Studies 75 (3), a50211. https://doi.org/10.4102/hts.v75i3.5021.Van Ummersen, Claire, Jean McLaughlin, and Lauren Duranleau. 2014. Faculty Retirement: Best Practices for Navigating the Transition. Sterling: Stylus Publishing.

West, Gerald. 1995. Biblical Hermeneutics of Liberation: Modes of Reading the Bible in the South African Context. Second revised version. Pietermaritzburg: Cluster Publications.

2016. The Stolen Bible: From Tool of Imperialism to African Icon. Pietermaritzburg: Cluster Publications. 